\title{
Inhibition of Topoisomerase II Activity in CHO K1 Cells by 2-[(Aminopropyl)Amino]Ethanethiol (WR-1065)
}

\author{
David J. Grdina, ${ }^{1,2}$ Andreas Constantinou, ${ }^{3} \&$ Naoyuki Shigematsu ${ }^{1}$
}

${ }^{1}$ Biological and Medical Research Division, Argonne National Laboratory, Argonne, llinois 60439, U.S.A.; ${ }^{2}$ Department of Radiation and Cellular Oncology, University of Chicago, Chicago, Illinois 60637, U.S.A.: ' ${ }^{3}$ Specialized Cancer Center, University of Illinois, Chicago, Illinois 60612, U.S.A.

Summary The aminothiol 2-[(aminopropyl)amino]ethanethiol (WR-1065) is the active thiol of the clinically studied radioprotective agent $S$-2-(3-aminopropylamino) ethylphosphorothioic acid (WR-2721). WR-1065 is an effective radiation protector and antimutagenic agent when it is administered $30 \mathrm{~min}$ prior to radiation exposure to Chinese hamster ovary $\mathrm{K} 1$ cells (i.e., a dose modification factor of 1.4) at a concentration of $4 \mathrm{mM}$. Under these exposure conditions, topoisomerase (topo) I and II activities and associated protein contents were measured in the $\mathrm{K} 1$ cell line using a DNA relaxation assay and immunoblotting. WR-1065 was ineffective in modifying topo I activity, but it did reduce topo II activity by 50 percent. The magnitude of topo II protein content, however, was not affected by these exposure conditions. Cell-cycle effects were monitored by the method of flow cytometry. Exposure of cells to $4 \mathrm{mM}$ of WR-1065 for a period of up to $3 \mathrm{~h}$ resulted in a buildup of cells in the G2 compartment. However, in contrast to topo II inhibitors used in chemotherapy, WR-1065 is an effective radioprotector agent capable of protecting against both radiation-induced cell lethality and mutagenesis. One of several mechanisms of radiation protection attributed to aminothiol compounds such as WR-1065 has been their ability to affect endogenous enzymatic reactions involved in DNA synthesis, repair, and cell-cycle progression. These results are consistent with such a proposed mechanism and demonstrate in particular a modifying effect by 2-[(aminopropyl)amino]ethanethiol on type II topoisomerase, which is involved in DNA synthesis.

Running Title: WR-1065 Affects Topoisomerase II Activity

Correspondence: $\quad$ D. J. Grdina

The submitted manuscript has been authored
by a contractor of the U.S. Government
under contract No. W-31-109ENG-38.
Accordingly, the U. S. Government retains a
nonexclusive. royalty-free license to publish
or reproduce the published form of this
contribution, or allow others to do so. for
U.S. Government purposes.

DISTRIBUTION OF THIS DOCUMENT IS UNLIMITED 


\section{DISCLAIMER}

Portions of this document may be illegible in electronic image products. Images are produced from the best available original document. 


\section{Introduction}

The phosphorothioate WR-2721 has been investigated in clinical trials as an adjuvant for use with radiation (Kligerman et al., 1988; Glover et al., 1988) and chemotherapy (Woolley et al., 1983; Glover et al., 1986a; Glover et al., 1986b) to reduce normal tissue toxicity. WR-2721 and its free thiol WR-1065 have also been reported to be effective in protecting against radiation- or chemotherapy-induced mutagenesis (Grdina et al., 1985; Nagy et al., 1986; Nagy \& Grdina, 1986; Kataoka et al., 1992; Grdina et al., 1992) and carcinogenesis (Milas et al., 1984; Grdina et al., 1991a; Carnes \& Grdina, 1992). With respect to the antimutagenic effect, these agents significantly reduced the frequency of mutations at the hprt locus in cultured mammalian cells and rodent $\mathrm{T}$ splenocytes, even when they were administered up to $3 \mathrm{~h}$ following exposure of cells to radiation (Grdina et al., 1985; Grdina et al., 1992).

The major mechanisms proposed to describe the protective effects of this class of aminothiols have focused on their well-characterized physiochemical properties which include free radical scavenging, hydrogen atom donation, and intracellular auto oxidation (Fahey, 1988). The aminothiols have also been implicated in affecting endogenous enzymatic processes in cells. These include DNA synthesis and repair (LaSalle \& Billen, 1964; Grdina \& Nagy, 1986), DNA nuclease activity (Grdina et al., 1989), and cell-cycle progression (Chatterjee \& Jacob-Raman, 1986; Sigdestad et al., 1988) in mammalian cells. As early as 1967, it was proposed that protection by aminothiol compounds is mediated via inherent cellular DNA repair processes (Brown, 1967). More recently it was reported that under extracellular conditions the disulfide form of WR-1065 can enhance the topoisomerase-I-mediated unwinding of supercoiled plasmid pIBI30 DNA (Holwitt et al., 1990). It was also suggested that this result was not unexpected due to the similarity in chemical structure between the disulfide form of WR-1065 and spermidine, 
a polyamine which has been reported to be effective in enhancing the relaxation of DNA supercoils via topoisomerase reactions (Srivenugopal \& Morris, 1985).

We have extended studies on the role of aminothiol-mediated effects on DNA-associated enzymes. In particular, we have characterized the effects of WR-1065 (the free thiol form of WR-2721) exposure on topo I and II activities in the CHO K1 cell line (Jeggo \& Kemp, 1983). Effects of WR-1065 on cell-cycle progression were also monitored using the method of flow cytometry.

\section{Materials and methods}

\section{Cells and culture conditions}

The CHO $\mathrm{K} 1$ cell line was maintained as a stock culture in $\alpha$-Minimal Essential Medium (Gibco) with $10 \%$ fetal calf serum (Biologos) in a humidified atmosphere containing $5 \% \mathrm{CO}_{2}$ and $95 \%$ air at $37^{\circ} \mathrm{C}$.

\section{Drug treatment}

WR-1065 used in these studies was supplied by the Drug Synthesis and Chemistry Branch, Division of Cancer Treatment, National Cancer Institute. The working solution of WR-1065 was made up in phosphate-buffered saline (PBS) (8.1 mM Na $\mathrm{HPO}_{4}, 1.5 \mathrm{mM} \mathrm{KH}_{2} \mathrm{PO}_{4}, 0.14 \mathrm{M} \mathrm{NaCl}$, $2.6 \mathrm{mM} \mathrm{KCl}$ ) buffer at a $1 \mathrm{M}$ concentration and sterilized by filtration immediately before use. Cells were exposed to WR-1065 at a final concentration of $4 \mathrm{mM}$. At that concentration, WR-1065 is nontoxic and is maximally effective as an antimutagen and a radioprotector (Grdina et al., 1985; Nagy et al., 1986; Nagy \& Grdina, 1986). 


\section{Survival studies}

Exponentially growing cultures of $\mathrm{K} 1$ cells were irradiated with $50-\mathrm{kVp}$-rays either in the presence or absence of WR-1065 (4 mM). All experiments were performed in triplicate. Cell survival was determined by plating appropriate numbers of cells to give between 80 and 200 colonies per dish, 6 dishes per experimental point. The $D_{0}$ and $95 \%$ confidence limits were determined for each survival curve using a computer-fitted, least-squares regression model. Dose modification factors were determined from survival curves by comparing the corresponding $D_{0}$ values obtained for each of the WR-1065 conditions with that of the associated radiation-only controls.

\section{Preparation of nuclear extracts}

Exponentially growing $\mathrm{CHO} \mathrm{K} 1$ cells were used in all experiments. Following exposure to radiation and/or WR-1065, treated and control cells in plastic petri dishes were placed on ice, and a volume (equal to that of the culture medium) of cold solution containing $50 \mathrm{mM}$ Tris- $\mathrm{HCl}$ ( $\mathrm{pH} 7.5$ ), $25 \mathrm{mM} \mathrm{KCl}, 2 \mathrm{mM} \mathrm{CaCl}, 3 \mathrm{mM} \mathrm{MgCl}_{2}$, and $0.25 \mathrm{M}$ sucrose was added. The cells

(about $10^{8}$ ) were centrifuged and then homogenized. The nuclei were isolated as described by Tandou et al. (1984) and extracted as described by Champoux and McConaughy (1976), except that immediately after the washing of cells, a solution comprised of $1 \mathrm{mM}$ phenylmethylsulfonyl fluoride, $1 \mathrm{mM}$ benzamidine, $10 \mu \mathrm{g} / \mathrm{ml}$ soybean trypsin inhibitor, $50 \mu \mathrm{g} / \mathrm{ml}$ leupeptin, $1 \mu \mathrm{g} / \mathrm{ml}$ pepstatin, and $20 \mu \mathrm{g} / \mathrm{ml}$ aprotinin was added. The protein content of the nuclear and the cellular extracts was determined by the Bradford method (Bradford, 1976). Glycerol was added to a final concentration of $30 \%$, and the extracts were stored at $-20{ }^{\circ} \mathrm{C}$. These preparations served as the source for topo I and II activity, as well as for topo II immunoblotting. For the unknotting assay (which detects topo II catalytic activity), serial dilutions were made such that the reaction 
volumes of $20 \mu \mathrm{l}$ contained a range of $50-800 \mu \mathrm{g}$ of nuclear extract. For the DNA relaxation assay (which detects topo I activity in the absence of ATP), reaction volumes of $20 \mu$ containing a range of $1-100 \mu \mathrm{g}$ of nuclear extract were used.

\section{Unknotting assay for the determination of topo II activity}

The enzyme sources for this assay were from serial dilutions of nuclear extracts. The substrate used was knotted DNA that had been isolated from tailless capsids of the bacteriophage P4 Vir1 de110, according to a modification of the methods by Liu et al. (1981). Reaction mixtures of $20 \mu$ contained $50 \mathrm{mM}$ Tris- $\mathrm{HCl}, \mathrm{pH} 8.0,100 \mathrm{mM} \mathrm{KCl}, 10 \mathrm{mM} \mathrm{MgCl}, 0.5 \mathrm{mM}$ dithiothreitol, $0.5 \mathrm{mM}$ EDTA, $40 \mu \mathrm{g} / \mathrm{ml}$ bovine serum albumin (nuclease free), and $1 \mathrm{mM}$ ATP. The reactions were started by the addition of $0.6 \mu \mathrm{g}$ of knotted DNA and terminated by the addition of $5 \mu \mathrm{l}$ of a stop solution containing 5\% sodium dodecyl sulfate (SDS), $50 \mathrm{mM}$ EDTA, 25\% Ficol, and $0.05 \mathrm{mg} / \mathrm{ml}$ bromophenol blue. Samples were loaded on $0.8 \%$ agarose gels and electrophoresed at $1.5 \mathrm{~V} / \mathrm{cm}$ for $15 \mathrm{~h}$ in Tris/Borate/EDTA buffer. Gels were stained in $1 \mu \mathrm{g} / \mathrm{ml}$ ethidium bromide and then destained and photographed over a UV light source. Quantitative determination of topo II activity was determined by densitometric measurement of photographic negatives. DNA that remained knotted migrated as a single band to the top of the gels. One unit of unknotting activity is defined as the amount of enzyme that converts $50 \%$ of the substrate (knotted DNA) into the reaction product (unknotted DNA).

\section{Relaxation assay for the determination of topo I activity}

The substrate used in this assay was pUC8 plasmid DNA (90\% supercoiled). Each reaction volume of $20 \mu \mathrm{l}$ contained $50 \mathrm{mM}$ Tris- $\mathrm{HCl}, \mathrm{pH} 7.4,50 \mathrm{mM} \mathrm{KCl}, 10 \mathrm{mM} \mathrm{MgCl}, 1 \mathrm{~mm}$ dithiothreitol, $0.1 \mathrm{mM}$ EDTA, and $30 \mu \mathrm{g} / \mathrm{ml}$ bovine serum albumin (nuclease free). Serial dilutions of the nuclear extracts served as the source of topo I. The reactions were started by the 
addition of $0.6 \mu \mathrm{g}$ of the supercoiled plasmid DNA. Following $30-$ min incubations at $37^{\circ} \mathrm{C}$, the reactions were terminated by the addition of $5 \mu \mathrm{l}$ of a stop solution containing $50 \%$ sucrose, 2\% SDS, $0.2 \mathrm{~m}$ EDTA, and $0.05 \%$ bromophenol blue. Samples were loaded in $0.8 \%$ gels, electrophoresed in Tris/Borate/EDTA buffer, stained, and photographed. Densitometric determination of the supercoiled form provided the means for quantitation. One unit of relaxation is defined as the amount of enzyme that converts $50 \%$ of the substrate (supercoiled DNA) into the reaction product (relaxed DNA). The omission of ATP from the assay eliminated the interference of topo II activity (Potmesil et al., 1988).

Immunoblotting for determining the topo II protein levels

Protein content of nuclear and cellular extracts were routinely determined (Bradford, 1976). Extracts containing $100 \mu \mathrm{g}$ of protein were analyzed in 8\% SDS polyacrylamide gels (Laemmli, 1970). Proteins were transferred electrophoretically to nitrocellulose membranes and incubated with an anti-topo-II antibody recognizing the carboxyl terminal portion of the human topo II. This polypeptide was produced by an expression plasmid p56 z11-1.8 (Hwang et al., 1989). The secondary antibody was anti-rabbit igG. Detection of the bands (corresponding to the $170 \mathrm{kDa}$ [kilodalton] form of topo II) was with the peroxidase reaction (Sigma) using 4-chloro-1-naphthol (Sigma) as the color indicator.

\section{Flow cytometry analysis}

The determination of the DNA content of control and treated V79 cells as well as the evaluation of the effects of WR-1065 on cell-cycle progression was made using the technique of flow cytometry (FCM). Cells were stained with DAPI (4',6-diamidino-2-phenylindole) (Russell et al., 1975 ) in a $0.1 \%$ citrate solution according to a method described elsewhere (Göhde et al., 1979). FCM patterns were obtained using a PARTEC PAS-II (Particle Analyzing System, Partec AG, 
Basel, Switzerland) and were analyzed using a computer program obtained from Phoenix Flow Systems, Inc. (San Diego, California, U.S.A.). The coefficient of variation (cv) of the G1 peak obtained using unperturbed cell samples routinely ranged from 1.5 to $2.5 \%$.

\section{Results}

WR-1065. effects on radiation response of $K 1$ cells

Treatment of $\mathrm{K} 1$ cells with $4 \mathrm{mM}$ of WR-1065 for $30 \mathrm{~min}$ prior to their exposure to $50-\mathrm{kVp}$ $\mathrm{x}$-rays resulted in significant radiation protection, as evidenced by an increase in the survival curve parameter $D_{0}$ (i.e., a measure of the terminal slope of the curve) from $2.35 \pm 0.15$ Gy to $3.35 \pm 0.25 \mathrm{~Gy}$ (Figure 1 ). The $\mathrm{D}_{0}$ values and associated $95 \%$ confidence limits were based on a computer-fitted least-squares regression model (Grdina et al., 1985). A dose modifying factor (DMF) of 1.4 was determined by taking the ratio of $D_{0}$ values from the survival curves describing the response of $\mathrm{K} 1$ cells in the presence and absence of WR-1065.

\section{WR-1065 effects on the activities of topoisomerases I and II}

Topo I and II activities were measured in untreated $\mathrm{K} 1$ cells along with (a) cells exposed to WR-1065 at a concentration of $4 \mathrm{mM}$ for $30 \mathrm{~min}$, (b) cells exposed to $10 \mathrm{~Gy}$ of ionizing radiation, and (c) cells exposed to WR-1065 and ionizing radiation. Presented in Figure 2 are data from a representative experiment describing topo II (panel A) and topo I (panel B) activities in nuclear extracts of $\mathrm{K} 1$ cells. Described in panel $\mathrm{A}$ are the activities of protein extracts from untreated or WR-1065-exposed K1 cells: $80 \mathrm{ng}$ in lane 1, $40 \mathrm{ng}$ in lane 2, $20 \mathrm{ng}$ in lane 3, $10 \mathrm{ng}$ in lane 4 , and $5 \mathrm{ng}$ in lane 5.

Topo I activity from nuclear extracts of $100 \mathrm{ng}$ (lane 1), $30 \mathrm{ng}$ (lane 2), $10 \mathrm{ng}$ (lane 3), $3 \mathrm{ng}$ (lane 4), $1 \mathrm{ng}$ (lane 5), and no extract (-) are described in panel B for control and WR-1065- 
treated $\mathrm{K} 1$ cells. Densitometric data from four replicate experiments describing topo I and topo II activities from K1 cells are summarized in Table 1. WR-1065 exhibited no effect on topo I activity in $\mathrm{K} 1$ cells (all groups compared to controls, $\mathrm{p} \geq 0.5$ ). Topo II activity was, however, significantly reduced following exposure to WR-1065, as compared to the untreated control $(p=0.019)$. Following irradiation and exposure to WR-1065, topo II activity was somewhat reduced; the level of significance, however, is only suggestive ( $p$ value of 0.061 ).

Since WR-1065 only affected topo II activity, topo II protein content was also determined for $\mathrm{K} 1$ cells exposed to WR-1065. Following exposure to $4 \mathrm{mM}$ of WR-1065 for $30 \mathrm{~min}$, exponentially growing $\mathrm{K} 1$ cells were lysed, and protein from nuclear extracts were electrophoresed in $8 \%$ SDS polyacrylamide gels and transferred to nitrocellulose. Blots were incubated with anti-topo-II antibody, and resulting data are presented in Figure 3. The molecular weights presented on the right ordinate are those of topo II (MW 170,000) and its proteolytic products. Prestained standards with associated molecular weights are also presented on the left side ordinate. Untreated control cells are represented in lane 1, WR-1065-treated cells are in lane 2, irradiated cells are in lane 3, and irradiated cells treated with WR-1065 are in lane 4. A proteolytic band with a molecular weight of $150 \mathrm{kDa}$ is also evident. Densitometric measurements of protein content ( $150 \mathrm{kDa}$ and $170 \mathrm{kDa}$ bands) are presented in Table 2 for comparison. No significant differences in topo II protein content were observed between any of the experimental groups $(\mathrm{p} \geq 0.30)$.

Determinations of topo II protein contents in cellular lysates of $\mathrm{K} 1$ cells were also performed, and data from a representative experiment are presented in Figure 4. Under these conditions, only a single major band of topo II was observed for $\mathrm{K} 1$ cells, suggesting that the minor band at $150 \mathrm{kDa}$ was due to enhanced proteolytic activity by this cell line. 
As presented in Figure 5, exposure of $\mathrm{K} 1$ cells to $4 \mathrm{mM}$ of WR-1065 for up to $3 \mathrm{~h}$ gave rise to a buildup of cells in the G2 phase of the cell cycle. The percent of cells in G1 fell from 37 to 29 over this period of time, while the percent of cells in G2 increased from 16 to 23 . the relative percent of cells in S phase was relatively constant, fluctuating only from 47 to 50 .

\section{Discussion}

Aminothiols such as WR-1065, cysteamine, or glutathione have been reported to be effective in inhibiting DNA synthesis (LaSalle \& Billen, 1964), strand rejoining (Holwitt et al., 1990), nuclease activity (Grdina et al., 1989), and cell-cycle progression (Sigdestad et al., 1988) in mammalian cells. These effects on cellular enzymatic processes have led investigators to propose that one possible mechanism of aminothiol protection involves the modulation of endogenous enzyme processes (Riklis et al., 1988).

Radiation protection studies performed on DNA repair-deficient organisms strongly support the suggestion that endogenous enzyme systems are dominant parameters which can influence the magnitude of aminothiol-mediated protection. While cysteamine was found to be an effective protective agent in wild-type $E$. coli, it was not protective in bacterial strains with defects in the rec system (Hulsewede \& Schulte-Frohlinde, 1986; Korystov \& Vexler, 1988). E. coli mutants deficient in poL I or UV endonucleases were also not amenable to protection by cysteamine (Korystov \& Vexler, 1988). Likewise, x-ray repair-deficient rad mutants of Saccharomyces cerevisia were reported to be unprotectable by cysteamine (Petin \& Matrenina, 1981). Protection by cysteamine against radiation damage wás observed only in diploid wild-type yeast. In addition, WR-1065 was found not to be protective against the lethal effects of radiation on the mutant xrs-5 CHO cell line (Grdina et al., 1991b). 
The aminothiols exhibit close structural similarities to polyamines, which are endogenous polybasic molecules having an affinity for DNA (Held \& Awad, 1991). The disulfide form (designated WR-33278) of the free thiol WR-1065 has the structure $\mathrm{H}_{2} \mathrm{~N}-\left(\mathrm{CH}_{2}\right)_{3}-\mathrm{NH}-\left(\mathrm{CH}_{2}\right)_{2}-\mathrm{S}-\mathrm{S}-\left(\mathrm{CH}_{2}\right)_{2}-\mathrm{NH}-\left(\mathrm{CH}_{2}\right)_{3}-\mathrm{NH}_{2}$, which is very similar to the structure of spermine (i.e., $\left.\mathrm{H}_{2} \mathrm{~N}-\left(\mathrm{CH}_{2}\right)_{3}-\mathrm{NH}-\left(\mathrm{CH}_{2}\right)_{2}-\left(\mathrm{CH}_{2}\right)_{2}-\mathrm{NH}-\left(\mathrm{CH}_{2}\right)_{3}-\mathrm{NH}_{2}\right)$. Spermine, in turn, has been observed to enhance the formation of a stable noncovalent complex between mammalian topo II and DNA (Pommier et al., 1989). It also has been reported that WR-2721 and its metabolites WR-1065 and WR-33278 can act as effective substrates and compete with polyamines for uptake into rat lung slices via well characterized polyamine transport processes (Wyatt et al., 1989). These compounds are also effective substrates for polyamine oxidase activity (Gaugas, 1982). Both aminothiols and polyamines can interact directly with and bind to DNA (Zheng et al., 1988; Vertino et al., 1987).

Interest in assessing the effect(s) of the aminothiol WR-1065 on enzymatic activities in K1 cells was prompted in part by these considerations. The focus of this study was limited to an investigation of topo I and II because these enzymes are known to be important in DNA synthesis (Hickson et al., 1990; Smith, 1990). In contrast to an earlier report in which a cell-free system was used to demonstrate that the disulfide form (WR-33278) of WR-1065 was effective in stimulating the eukaryotic topo I unwinding of negatively supercoiled DNA (Holwitt $e t$ al., 1990), we were unable to observe any effect of WR-1065 at a concentration of $4 \mathrm{mM}$ on topo I activity in $\mathrm{K} 1$ cells.

When nuclear lysates were used to measure topo II content, a $150-\mathrm{kDa}$ band also was observed. The presence of this band suggests the occurrence of proteolytic activity in the cellular 
preparations. The use of rapid cellular lysates, in contrast, demonstrates the presence of only one topo II band at $170 \mathrm{kDa}$ (see Figure 4).

Topo I and II activities were unaffected in $\mathrm{K} 1$ cells following exposure to ionizing radiation only. However, WR-1065 was effective in inhibiting topo II activity. The implications of this phenomenon are at present unclear. Consistent with this inhibition of topo II activity, however, was the demonstration that exposure of cells to WR-1065 also induced an arrest of cells in the G2/M phase of the cell cycle (see Figure 5). Topo II poisons such as VP-16, VM-26, and mAMSA are known to induce G2/M phase arrest in cells (Constantinou et al., 1992). These agents are potent cytotoxins which inhibit cell-cycle progression as a result of their ability to stabilize the reaction intermediate between topo II and DNA (Liu, 1989). WR-1065, in contrast, is an effective radioprotector which is routinely used to enhance cell survival following irradiation or exposure to chemical toxins. The mechanism underlying the ability of WR-1065 to inhibit topo II activity may be more analogous to that attributed to spermine and spermidine (Pommier et al., 1989). These polyamines are capable of enhancing the formation of a stable noncovalent complex between topo II and DNA, thus facilitating a stimulation of the enzymatic relaxation of DNA. In contrast to the covalent cleavable complexes induced by topo II poisons, the polyamine-induced complex is not associated with the irreversible induction of DNA strand breaks but appears to be part of an endogenous regulatory mechanism involved in DNA synthesis (Pommier et al., 1989).

Historically, the focus of studies on the mechanism of action of radiation and chemoprotection has centered on the physiochemical properties of the proposed protective agents. In particular, emphasis has been directed toward assessing the abilities of protectors to scavenge free radicals, participate in chemical repair processes via the donation of hydrogen atoms, and 
the induction of auto oxidation processes. Another parameter now garnering attention is the ability of these agents to influence endogenous enzymatic processes which, in turn, would influence cellular responses to radiation and chemical insult. The close structural similarity between aminothiols (i.e., WR-1065) and polyamines (i.e., spermidine and spermine) suggest that there may also be a similarity in the mechanism of action exhibited by these agents on cellular enzyme activities involved in DNA synthesis, cell-cycle progression and, possibly, repair. In particular, these results extend earlier observations (Hulsewede \& Schulte-Frohlinde, 1986; Korystov \& Vexler, 1988; Petin \& Matrenina, 1981) of aminothiol interactions with cellular enzymes to now include the ability of WR-1065 to affect the nuclear enzyme topoisomerase II.

\section{Acknowledgments}

The authors thank P. Dale for her technical assistance. We also thank Dr. B. Carnes for his assistance in data analysis and statistics and J. Lear for her help in the preparation of this manuscript.

This investigation was supported by the U.S. Department of Energy under Contract No. W-31-109-ENG-38, by NIH/National Cancer Institute Grant CA-37435, and by the Center for Radiation Therapy.

\section{DISCLAIMER}

This report was prepared as an account of work sponsored by an agency of the United States Government. Neither the United States Government nor any agency thereof, nor any of their employees, makes any warranty, express or implied, or assumes any legal liability or responsibility for the accuracy, completeness, or usefulness of any information, apparatus, product, or process disclosed, or represents that its use would not infringe privately owned rights. Reference herein to any specific commercial product, process, or service by trade name, trademark, manufacturer, or otherwise does not necessarily constitute or imply its endorsement, recommendation, or favoring by the United States Government or any agency thereof. The views and opinions of authors expressed herein do not necessarily state or reflect those of the United States Government or any agency thereof. 


\section{REFERENCES}

BRADFORD, M.M. (1976). A rapid and sensitive method for the quantitation of microgram quantities of protein utilizing the principle of protein-dye binding. Anal. Biochem., 72, 248-254.

BROWN, P.E. (1967). Mechanism of action of aminothiol radioprotectors. Nature, 213, $363-364$.

CARNES, B.A. \& GRDINA, D.J. (1992). In vivo protection by the aminothiol WR-2721 against neutron-induced carcinogenesis. Int. J. Radiat. Biol., 61, 567-576.

CHAMPOUX, J.J. \& MCCONAUGHY, B. (1976). Purification and characterization of the DNA untwisting enzyme from rat liver. Biochemistry, 15, 4638-4642.

CHATTERJEE, A. \& JACOB-RAMAN, M. (1986). Modifying effect of reduced glutathione and $\mathrm{x}$-ray-induced chromosome aberration and cell-cycle delay in mutagenic lymphocytes in vitro. Mutat. Res., 175, 73-82.

FAHEY, R.C. (1988). Protection by thiols. Pharmacol. Ther., 39, 101-108.

GAUGAS, J.M. (1982). Possible association of radioprotective and chemoprotective aminophosphorothioate drug activity with polyamine oxidase susceptibility. J. Nat. Cancer Inst., 69, 329-332.

GLOVER, D., FOX, K.R., WEILER, C., KLIGERMAN, M.M., TURRISI, A. \& GLICK, J.H. (1988). Clinical trials of WR-2721 prior to alkylating agent chemotherapy and radiotherapy. Pharmacol. Ther., 39, 3-7.

GLOVER, D., GLICK, J.H., WEILER, C., FÓX, K., TURRISI, A. \& KLIGERMAN, M.M. (1986a). Phase I/II trials of radiation and cis-platinum. Int. J. Radiat. Oncol. Biol. Phys., 12, 1509-1512. 
GLOVER, D., GLICK, J.H., WEILER, C., HUROWITZ, S. \& KLIGERMAN, M.M. (1986b). WR-2721 protects against the hematologic toxicity of cyclophosphamide: a controlled Phase II trial. J. Clin. Oncol., 4, 584-588.

GöHDE, W., SCHUMANN, J., BUCHNER, T., OTTO, F. \& BARLOGIE, B. (1979). Pulse cytophotometry: application in tumor and cell biology and clinical oncology. In Cytometry and Sorting. Mehamed, M.R., Mulhaney, P.F. \& Mendelsohn, M.L. (eds) p. 599. John Wiley Pub.: New York.

GRDINA, D.J., CARNES, B.A., GRAHN, D. \& SIGDESTAD, C.P. (1991a). Protection against late effects of radiation by S-2-(3-aminopropylamino)ethylphosphorothioic acid. Cancer Res., 51, 4125-4130.

GRDINA, D.J., KATAOKA, Y., BASIC, I. \& PERRIN, J. (1992). The radioprotector WR-2721 reduces neutron-induced mutations at the hypoxanthine-guanine phosphoribosyl transferase locus in mouse splenocytes when administered prior to or following irradiation. Carcinogenesis, 13, 811-814.

GRDINA, D.J. \& NAGY, B. (1986). The effect of 2-[(aminopropyl)amino]ethanethiol (WR-1065) on radiation-induced DNA damage and repair and cell progression in V79 cells. Br. J. Cancer, 54, 933-941.

GRDINA, D.J., NAGY, B., HILL, C.K., WELLS, R.L. \& PERAINO, C. (1985). The radioprotector WR-1065 reduces radiation-induced mutations at the hypoxanthine-guanine phosphoribosyl transferase locus in V79 cells. Carcinogenesis, 6, 929-931. 
GRDINA, D.J., NAGY, B. \& MEECHAN, P.J. (1991b). Effect of an aminothiol (WR-1065) on radiation-induced mutagenesis and cytotoxicity in two repair-deficient mammalian cell lines. In Anticarcinogenesis and Radiation Protection 2. Nygaard, O.F. \& Upton, A.C. (eds) p. 287. Plenum Press: New York.

GRDINA, D.J., SIGDESTAD, C.P., DALE, P.J. \& PERRIN, J.M. (1989). The effect of 2-[(aminopropyl)amino]ethanethiol on fission-neutron-induced DNA damage and repair. Br. J. Cancer, 59, 17-21.

HELD, K.D. \& AWAD, S. (1991). Effects of polyamines and thiols on the radiation sensitivity of bacterial transforming DNA. Int. J. Radiat. Biol., 59, 699-710.

HICKSON, I.D., DAVIES, S.L., DAVIES, S.M. \& ROBSON, C.N. (1990). DNA repair in radiation-sensitive mutants of mammalian cells: possible involvement of DNA topoisomerases. Int. J. Radiat. Biol., 58, 561-568.

HOLWTT, E.A., KODA, E. \& SWENBERG, C.E. (1990). Enhancement of topoisomerase Imediated unwinding of supercoiled DNA by the radioprotector WR-33278. Radiat. Res., 124, 107-109.

HULSEWEDE, J.W. \& SCHULTE-FROHLINDE, D. (1986). Radiation protection of E. Coli strains by cysteamine in the presence of oxygen. Int. J. Radiat. Biol., 50, 861-869.

HWANG, J., SHYY, S., CHEN, A.Y., JUAN, C.C. \& WHANG-PENG, J. (1989). Studies of topoisomerase-specific antitumor drugs in human lymphocytes using rabbit antisera against recombinant human topoisomerase II polypeptide. Cancer Res., 49, 958-962.

JEGGO, P.A. \& KEMP, L.M. (1983). X-ray, sensitive mutants of Chinese hamster ovary cell line: isolation and cross-sensitivity to other DNA-damaging agents. Mutat. Res., 112, 313327. 
KATAOKA, Y., BASIC, I., PERRIN, J. \& GRDINA, D.J. (1992). Antimutagenic effects of the radioprotector WR-2721 against fission-spectrum neutrons and ${ }^{60} \mathrm{Co} \gamma$-rays in mice. Int. J. Radiat. Biol., 61, 387-392.

KLIGERMAN, M.M., TURRISI, A.T., URTASUN, R.C., NORFLEET, A.L., PHILLIPS, T.L., BARKLEY, T. \& RUBIN, P. (1988). Final report on Phase I trial of WR-2721 before protracted fractionated radiation therapy. Int. J. Radiat. Oncol. Biol. Phys., 14, 1119-1122.

KORYSTOV, Y.N. \& VEXIER, F.B. (1988). Mechanisms of the radioprotective effect of cysteamine in Escherichia coli. Radiat. Res., 114, 550-555.

LAEMMLI, U.K. (1970). Cleavage of structural proteins during the assembly of the head of bacteriophage T4. Nature, 227, 680-685.

LASALLE, M. \& BILLEN, D. (1964). Inhibition of DNA synthesis in murine bone marrow cells by AET and cysteamine. Ann. New York Acad. Sci., 114, 622-628.

LIU, L.F. (1989). DNA topoisomerase poisons as antitumor drugs. Annu. Rev. Biochem., $58,351-375$.

LIU, L.F., DAVIS, J.L. \& CALENDAR, R. (1981). Novel topologically knotted DNA from bacteriophage P4 capsids: studies with DNA topoisomerases. Nucleic Acids Res., 9, 3979-3989.

MILAS, L., HUNTER, N., STEPHENS, C.L. \& PETERS, L.J. (1984). Inhibition of radiation carcinogenesis by S-2-(3-aminopropylamino)ethylphosphorothioic acid. Cancer Res., 44, 5567-5569.

NAGY, B., DALE, P.J. \& GRDINA, D.J. (1986). Protection against cisdiamminedichloroplatinum cytotoxicity and mutagenicity in V79 cells by 2-[(aminopropyl)amino]ethanethiol. Cancer Res., 46, 1132-1135. 
NAGY, B. \& GRDINA, D.J. (1986). Protective effects of 2-[(aminopropyl)amino]ethanethiol against bleomycin and nitrogen mustard-induced mutagenicity in V79 cells. Int. J. Radiat. Oncol. Biol. Phys., 12, 1475-1478.

PETIN, V.G. \& MATRENINA, V.L. (1981). Radioprotecting action of chemical compounds in $\gamma$-irradiated yeast cells of various genotypes. Mol. Gen. Genet., 183, 152-157.

POMMIER, Y., KERRIGAN, D. \& KOHN, K. (1989). Topological complexes between DNA and topoisomerase II and effects of polyamines. Biochemistry, 28, 995-1002.

POTMESIL, M., HSIANG, Y-H., LIU, L.F., BANK, B., GROSSBERG, H., KIRSCHENBAUM, S., FORLENZAR, T.J., PENZINER, A., KANGANIS, D., KNOWLES, D., TRAGANOUS, F. \& SILBER, R. (1988). Resistance of human leukemic and normal lymphocytes to drug-induced DNA cleavage and low levels of DNA topoisomerase II. Cancer Res., 48, 3537-3543.

RIKLIS, E., IOL, R., GREEN, M., PRAGER, A., MARKO, R. \& MINTSBERG, M. (1988). Increased radioprotection attained by DNA repair enhancement. Pharmacol. Ther., 39, 311-322.

RUSSELL, W.C., NEWMAN, C. \& WILLIAMSON, D.H. (1975). A simple cytochemical technique for demonstration of DNA in cells infected with mycoplasma and viruses. Nature, 253, 461-463.

SIGDESTAD, C.P., GUILFORD, W., PERRIN, J. \& GRDINA, D.J. (1988). Cell cycle redistribution of cultured cells after treatment with chemical radiation protectors. Cell Tissue Kinet., 21, 193-200.

SMITH, P.J. (1990). DNA topoisomerases and radiation responses. Int. J. Radiat. Biol., 58, 553-559. 
SRIVENUGOPAL, K.S. \& MORRIS, D.R. (1985). Differential modulation by spermidine of reactions catalyzed by type I prokaryotic and eukaryotic topoisomerases. Biochemistry, 24, $4766-4771$.

TANDOU, G., MIRAMBEAU, G., LAVENOT, C., GARABEDIAN, A., VERMEERSCH, J. \& DOUGUET, M. (1984). DNA topoisomerase activities in concanavalin A-stimulated lymphocytes. FEBS Lett., 176, 431-435.

VERTINO, P.M., BERGERON, R.J., CAVANAUGH, P.F. \& PORTER, C.W. (1987). Structural determinants of spermidine interactions. Biopolymers, 26, 691-703.

WOOLLEY, P.E.V., III, AYOOB, M.J., SMITH, F.P. \& DRITSCHUL, A. (1983). Clinical trial of the effect of S-2-(3-aminopropylamino) ethylphosphorothioic acid (WR-2721) (NSC296961) on the toxicity of cyclophosphamide. J. Clin. Oncol., 1, 198-203.

WYATT, I., MOORE, R.B. \& SMITH, L.L. (1989). Competition for polyamine uptake into rat lung slices by WR2721 and analogues. Int. J. Radiat. Biol., 55, 463-472.

ZHENG, S., NEWTON, G.L., GONICK, G., FAHEY, R.C. \& WARD, J.F. (1988). Radioprotection of DNA by thiols: relationship between net change on a thiol and its ability to protect DNA. Radiat. Res., 114, 11-27. 
Table I The effects of WR1065 and radiation on the activities of topo I and II in K1 CHO cell lines, as determined by DNA relaxation and unknotting assays, respectively. ${ }^{\mathrm{a}}$

\begin{tabular}{|c|c|c|c|c|}
\hline $\begin{array}{c}\text { Cell } \\
\text { Type }\end{array}$ & $W R-1065$ & $\gamma-r a y$ & \multicolumn{2}{|c|}{ 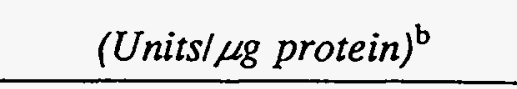 } \\
\hline $\mathrm{K} 1$ & - & - & $112 \pm 20$ & $59 \pm 14$ \\
\hline $\mathrm{K} 1$ & + & - & $97 \pm 28$ & $26 \pm 3^{c}$ \\
\hline $\mathrm{K} 1$ & - & + & $82 \pm 22$ & $53 \pm 28$ \\
\hline $\mathrm{K} 1$ & + & + & $96 \pm 28$ & $36 \pm 13^{d}$ \\
\hline
\end{tabular}

${ }^{a}$ Comparisons made to the corresponding untreated control groups using Student's 2-tailed T test. Comparisons not significant, $p \geq 0.386$, except as noted. ${ }^{b}$ Mean \pm S.D. of four experiments. 'Significant difference at $\mathrm{p}=0.019$. ${ }^{\mathrm{d}}$ Suggestive difference at $\mathrm{p}=0.061$. 
Table II The effects of WR1065 and radiation on the protein levels of topo II in $\mathrm{K} 1 \mathrm{CHO}$ cell lines, as determined by immunoblotting using an anti-topo II specific antibody.

\begin{tabular}{cccc}
$\begin{array}{c}\text { Cell } \\
\text { Type }\end{array}$ & WR-1065 & $\gamma-$ ray & $100 \times$ Area $^{\mathrm{b}}$ \\
\hline $\mathrm{K} 1$ & - & - & $167 \pm 55$ \\
$\mathrm{~K} 1$ & + & - & $179 \pm 49$ \\
$\mathrm{~K} 1$ & - & + & $219 \pm 21$ \\
$\mathrm{~K} 1$ & + & + & $163 \pm 39$ \\
\hline
\end{tabular}

${ }^{a}$ Comparisons made to the corresponding untreated control groups using Student's 2-tailed $T$ test. All comparisons not significant, $p \geq 0.300$. bean \pm S.D. of at least three experiments. 


\section{FIGURE LEGENDS}

Figure 1 Survival curves for $\mathrm{K} 1$ cells irradiated with $50-\mathrm{kVp}$-rays. Cells were either treated with $4 \mathrm{mM}$ of WR-1065 (⿴) or untreated $(\bullet)$. Experimental points represent the mean of three experiments; error bars represent the standard error of the mean. Survival curve parameters were determined by using a computer-fitted least-squares regression model.

Figure 2 Topo II (panel A) and topo I (panel B) activity in nuclear extracts from untreated and WR-1065-treated K1 cells. Nuclear extracts containing the following amounts of protein were assayed for topo-II-mediated unknotting and topo-I-mediated relaxing activities, as described in Methods: panel A, lane 1, $80 \mathrm{ng}$; lane 2, $40 \mathrm{ng}$; lane 3, $20 \mathrm{ng}$; lane 4, $10 \mathrm{ng}$; lane 5, $5 \mathrm{ng}$; panel $\mathrm{B}$, lane 1, $100 \mathrm{ng}$; lane 2, $30 \mathrm{ng}$; lane 3, $10 \mathrm{ng}$; lane 4, $3 \mathrm{ng}$; lane 5, $1 \mathrm{ng}$; $(-)$, no nuclear extract. This is a representative experiment. Data from four such experiments were used to determine the mean activities.

Figure 3 Immunoblot analysis of topo II levels in nuclear extracts from untreated and WR-1065-treated K1 cells. Logarithmically growing cells were washed twice by centrifugation at $1000 \times g$ for $5 \mathrm{~min}$ in PBS-containing protease inhibitors and extracts. Nuclear proteins were subjected to gel electrophoresis through an $8 \%$ SDS-polyacrylamide gel and transferred to nitrocellulose. Blots were incubated with anti-topo II antibody. The molecular weights shown on the right ordinate are those of topo II (MW 170,000) and its proteolytic products. Prestained standards with their molecular weights in thousands are shown on the left ordinate. Lane 1, untreated cells; lane 2, WR-1065-treated but unirradiated cells, lane 3; irradiated cells; lane 4, cells irradiated and treated with WR-1065. 
Figure 4 Immunoblot analysis of topo II levels in rapidly lysed cells. Conditions were similar to those described in Figure 3 with the exception that cells were lysed in electrophoresis sample buffer containing $2 \%$ SDS by boiling for $2 \mathrm{~min}$.

Figure 5 Typical flow cytometry patterns describing the DNA distribution of $\mathrm{K} 1$ cells exposed to $4 \mathrm{mM}$ WR-1065 for $0 \mathrm{~min}, 30 \mathrm{~min}, 1 \mathrm{~h}, 2 \mathrm{~h}$, and $3 \mathrm{~h}$. During the $3 \mathrm{~h}$ of exposure, the percent of cells in G1 fell from 37 to 29, while the percent of cells in G2 increased from 16 to 23. The percent of cells in $S$ ranged from 47 to 50 . 
Figure 1

Grdina, et al.

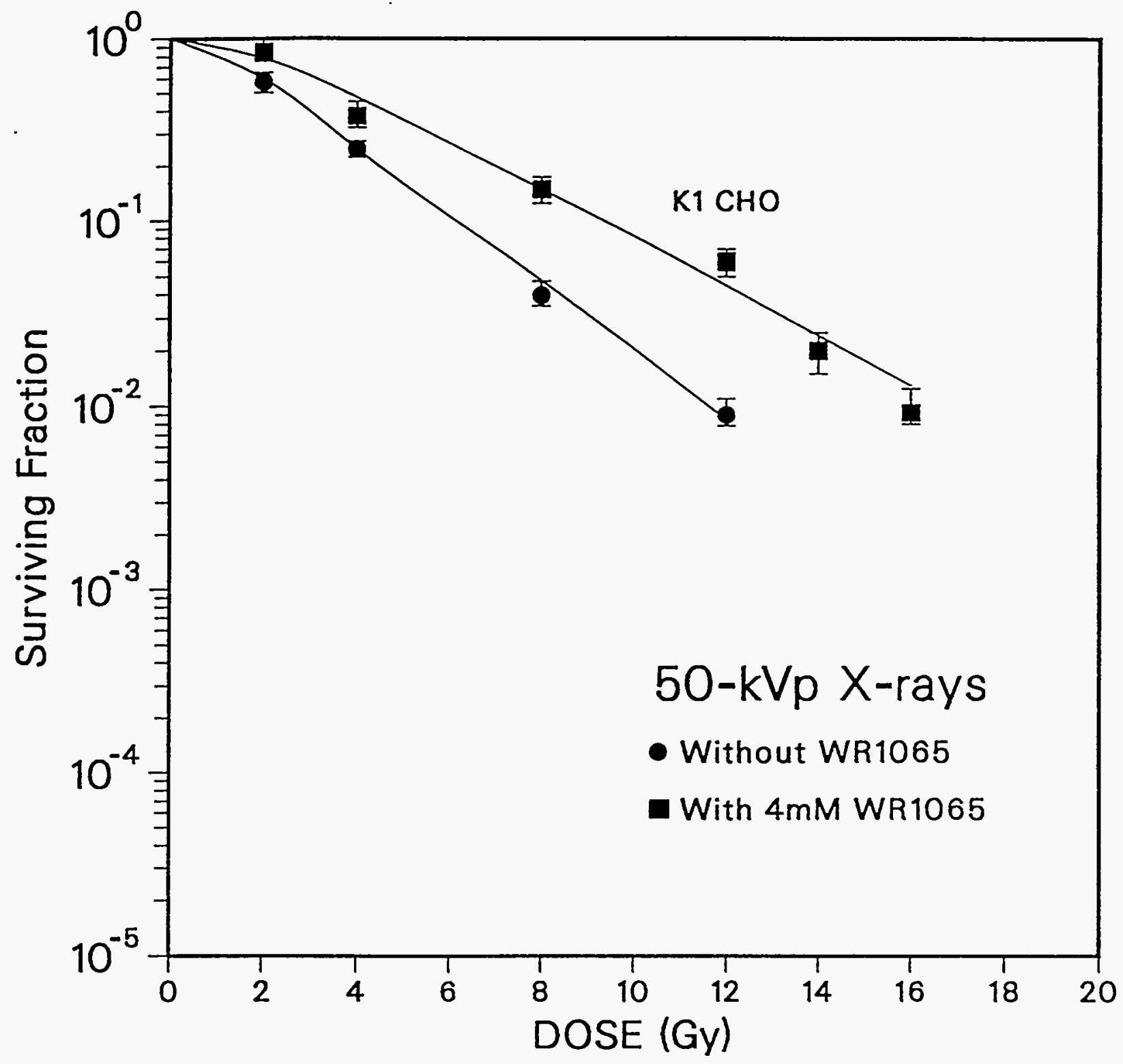


Figure 2

Grdina, et al.

A. CONTROL

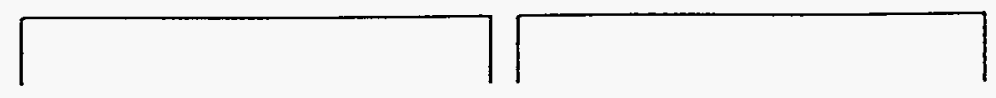

Unknotted

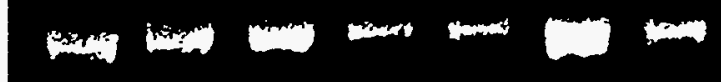

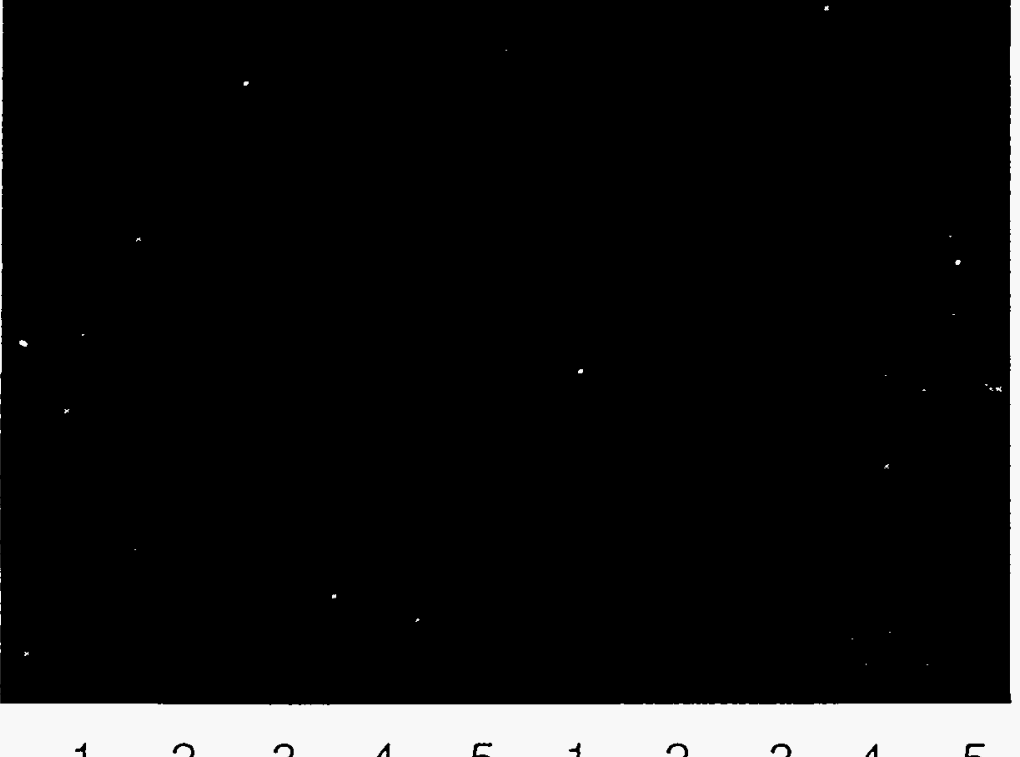

$\begin{array}{llllllllll}1 & 2 & 3 & 4 & 5 & 1 & 2 & 3 & 4 & 5\end{array}$

B. CONTROL WR1065

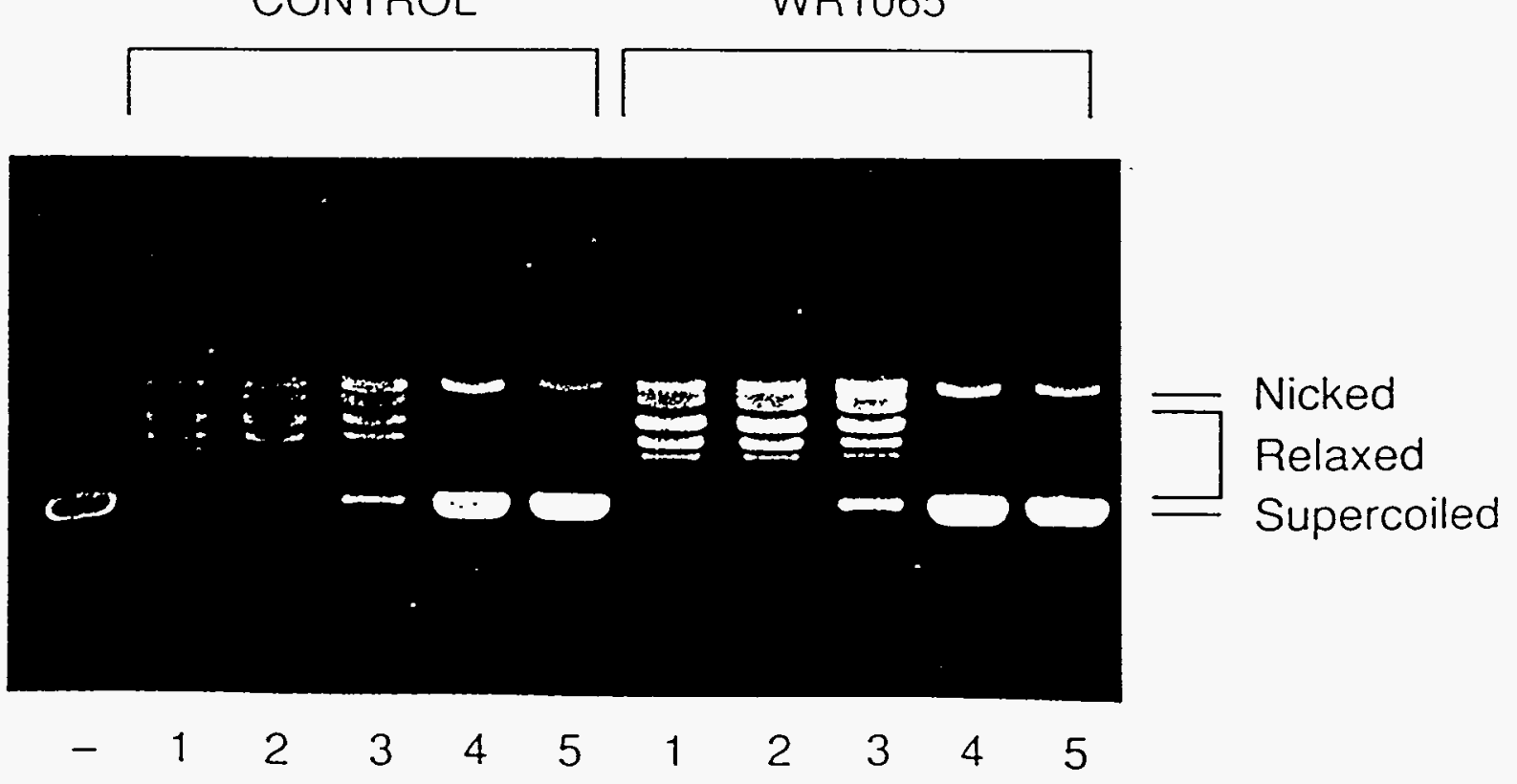



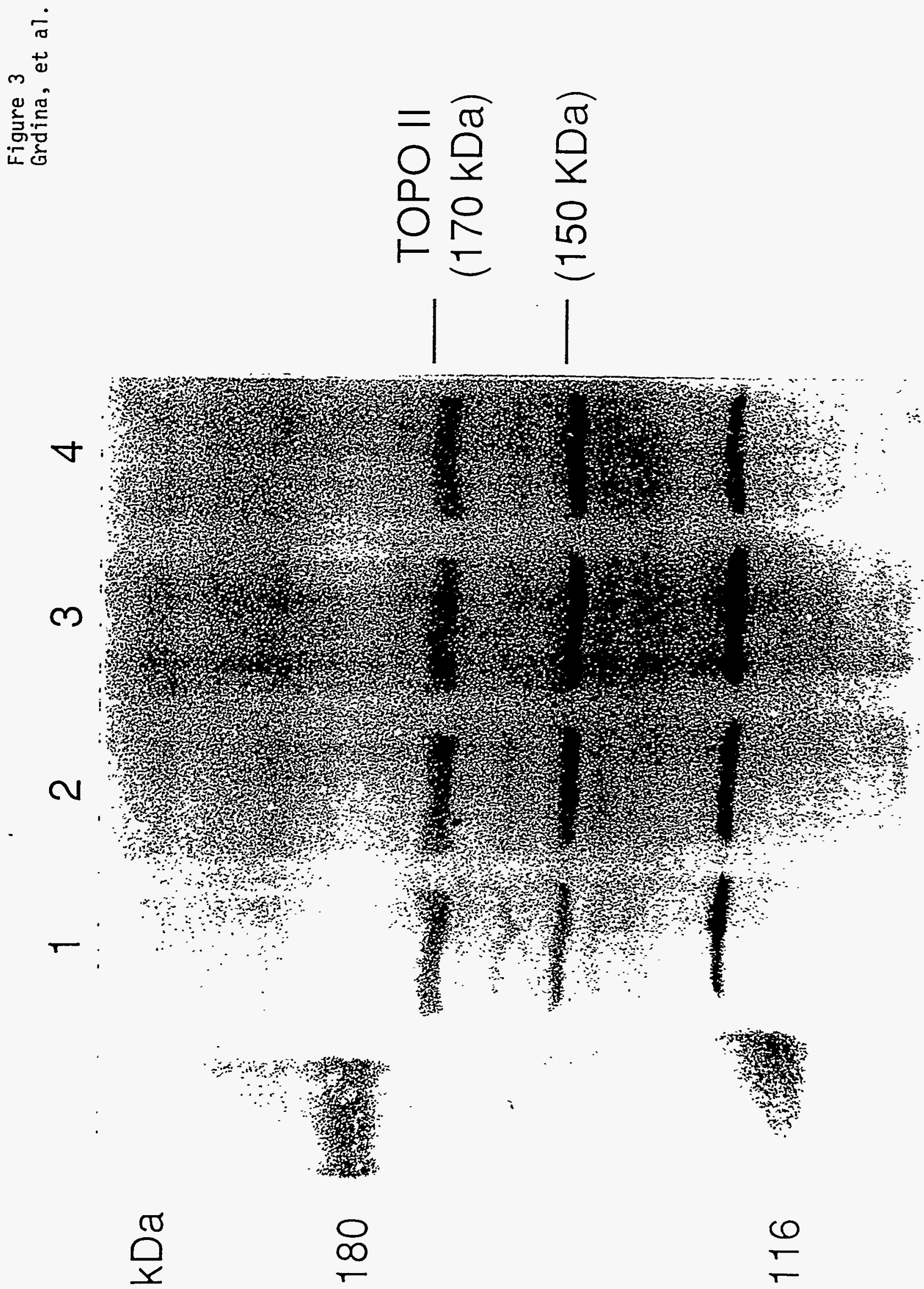
Figure 4

Grdina, et al.

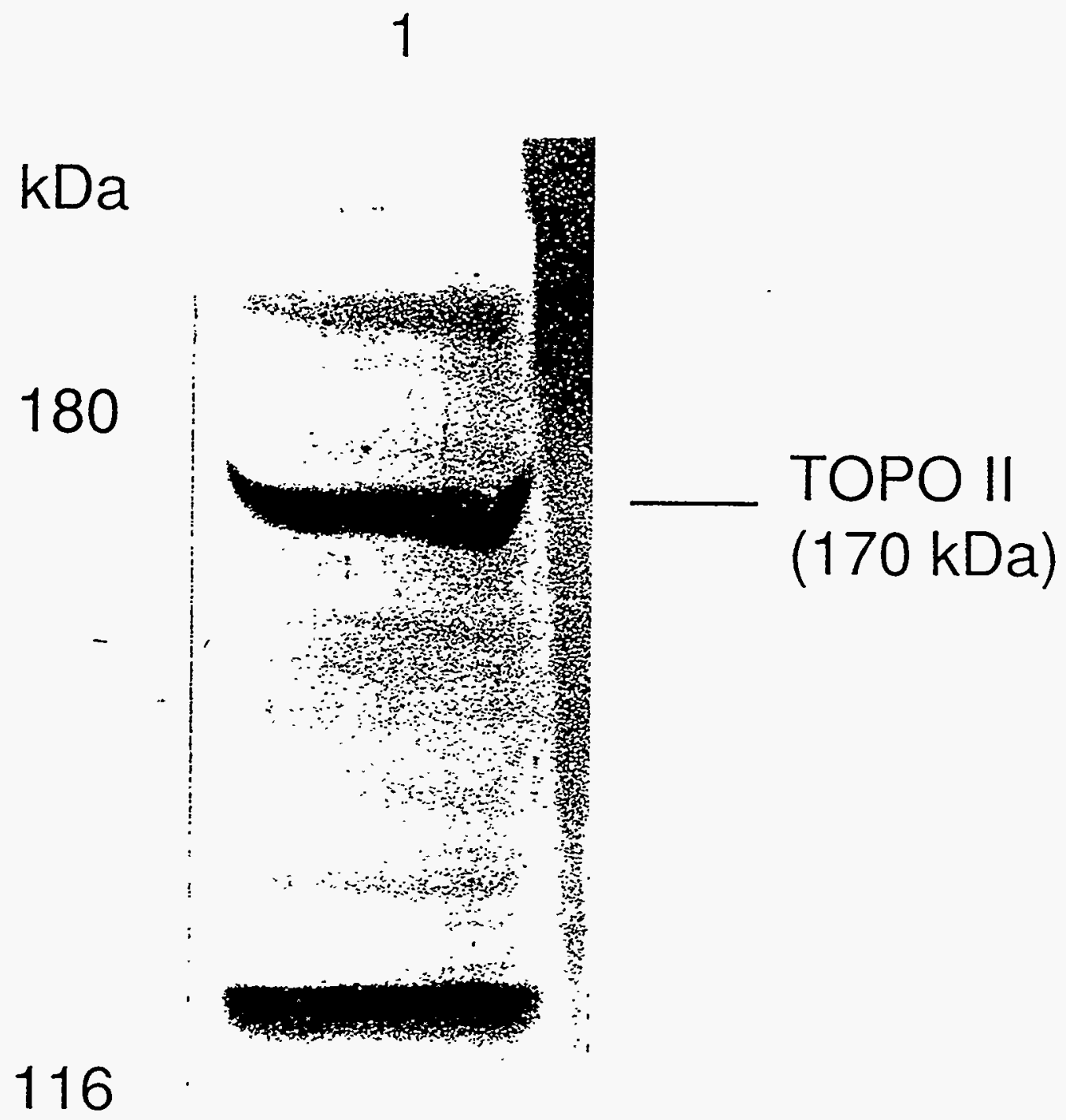


Figure 5

Grdina, et al.
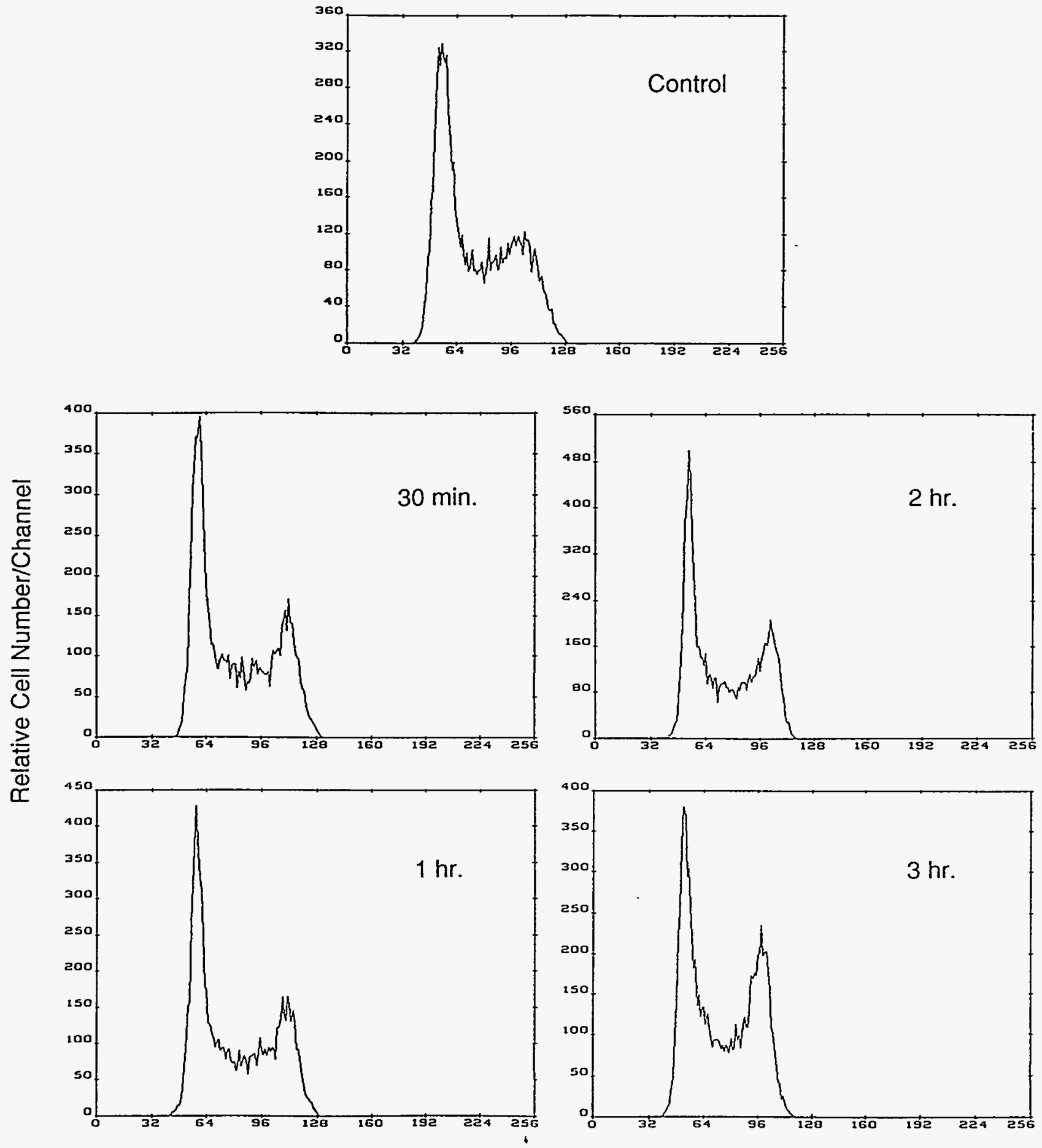

Channel Number 